\title{
The Fellows Project: Education Skills for Health Profession Students
}

\section{Projeto Fellows: Habilidades de Educação para Estudantes das Profissões da Saúde}

\author{
Ugo Caramori ${ }^{I}[\mathbb{D}$ \\ Júlia Brum de Mello ${ }^{I I} \mathbb{D}$ \\ Camila Azeredo Pereira Barretto ${ }^{\text {II }}$ (D) \\ Rafael de Madureira Ribas Costa ${ }^{I I}$ (D) \\ Stela Souza Peña ${ }^{I I}(\mathbb{D}$ \\ Ana Luisa Carneiro Ramos ${ }^{I I}$ iD \\ Fernando Antonio de Almeida ${ }^{I I}$ (D) \\ Maria Valéria Pavan ${ }^{I I}$ (D)
}

\section{KEYWORDS}

- Health Education.

- Medical Education.

- Students.

- Higher Education.

- Teaching.
IFaculdade de Ciências Médicas da UNICAMP, Campinas, São Paulo, Brazil.

${ }^{\mathrm{II}}$ Faculdade de Ciências Médicas e da Saúde da PUC-SP, campus Sorocaba, Sorocaba-SP, Brazil. 


\section{PALAVRAS-CHAVE}

- Educação em Saúde.

- Educação Médica.

- Estudante.

- Educação Superior

- Docência.

\section{RESUMO}

As novas tecnologias da informação produziram profundas transformações na educação e na sociedade. Todas as áreas do conhecimento têm sido constantemente reinventadas, readaptadas e recriadas para se ajustarem às novas exigências da prática profissional. A educação nas profissões da saúde também tem seguido esses passos. É nítido como os estudantes, futuros educadores, estão envolvidos nessa transformação e têm sido vetores dessas mudanças. Paralelamente, a concepção dos novos currículos para os cursos da área da saúde pressupõe a participação ativa dos estudantes na própria formação e na de seus pares. Essa nova forma de ensinar, que privilegia o trabalho em equipe, a aprendizagem por pares, a interdisciplinaridade e a autonomia, estimula e exige esse protagonismo dos estudantes. A participação ativa do estudante nas atividades educativas da graduação traz inúmeros benefícios: favorece o aprendizado, as relações interpessoais e a aquisição de habilidades de comunicação, de orientação, de liderança, de pesquisa e de gestão, e desenvolve a responsabilidade social. Os estudantes das profissões da saúde, mesmo nas fases mais precoces de formação, fazem suas escolhas e direcionam sua formação para o que desejam na vida profissional. Quando essa escolha recai sobre uma área específica da saúde, eles encontram, desde a graduação, maneiras de começar a desenvolver seus conhecimentos e habilidades em clínica médica, cirurgia, pediatria, pesquisa em laboratório, saúde pública e outras áreas, mas não encontram apoio à formação quando pretendem ser futuros professores. Nesse contexto, surgiu o Projeto FELLOWS, um projeto de desenvolvimento docente, proposto e conduzido por estudantes de Medicina, em blended learning (presencial e a distância) que tem como objetivos a formação e o aperfeiçoamento em habilidades de educação para estudantes das profissões da saúde, aqui apresentado como um relato de experiência. Em 2017, o projeto estendeu-se de abril a outubro em encontros mensais no horário noturno e, eventualmente, aos sábados. Foi conduzido por quatro estudantes de Medicina (coordenadores) e dois professores supervisores e contou com colaboradores de outras instituições de educação médica. Em 2018, as atividades educativas foram realizadas exclusivamente pelos estudantes/residentes coordenadores e os professores supervisores, por meio de duas sessões de imersão (sexta, sábado e domingo), separadas por um período de quatro meses em que foi elaborado um projeto de educação, construído em grupos de seis estudantes acompanhados por um tutor e um coordenador. As atividades do Projeto FELLOWS seguem as Diretrizes Curriculares Nacionais do Curso de Graduação em Medicina de 2001 e 2014, atendem às demandas da educação nas áreas da saúde no Brasil e respeitam o perfil desejado do profissional egresso, com responsabilidade social. Oferecem o contato e progressivo domínio de habilidades de comunicação e de competências para o trabalho docente, o uso de metodologias ativas de ensinoaprendizagem, o trabalho em equipe, o uso de tecnologias digitais, o exercício da comunicação oral e escrita e a criatividade para a inovação. O processo de execução do Projeto FELLOWS trouxe benefícios diretos para os organizadores e para os participantes, e benefícios indiretos para as instituições de ensino a que pertencem, pois envolveu produção de conhecimento, engajamento estudantil e responsabilidade social.

Received on 10/22/19

Accepted on $12 / 10 / 19$

\section{INTRODUCTION AND CONTEXT}

The introduction and consolidation of information technology has resulted in profound changes in education and society. All areas of knowledge have been constantly reinvented, readapted and recreated to adjust to the new professional practice requirements. Education in the health professions has also followed these steps. For many education specialists, the way students are involved in this transformation is clear and has been the vectors of these changes, mainly because today's university students have grown immersed in this new reality of connections and innovations. The student, who has followed and caused all these changes during graduation, will be the future educator.

In parallel, the design of the new curricula for courses in the health area is based on the assumption of the active participation of students not only in their own training, but also in that of their peers ${ }^{1,2}$. This new way of teaching, which privileges teamwork, teaching/learning by peers, interdisciplinarity and autonomy, stimulates and demands this leadership role from students. The student's active participation in the graduation's educational activities brings numerous benefits as already analyzed by many authors. It favors learning; interpersonal relationships (e.g. doctorpatient); the acquisition of communication, orientation, leadership, research and management skills and, very importantly, develops the student's social accountability ${ }^{3,4}$.

As in other areas of knowledge, students in the health professions, even at the earliest stages of their training, make their choices and develop their training, directed to what they want in their professional life. When this choice falls on a specific area of health, they find the embracing, since undergraduate school, to continue to develop their knowledge and skills in clinical medicine, surgery, pediatrics, laboratory research, public health and other areas, but they do not find this type of support for training when they intend to be a future teacher.

Within this context, the FELLOWS Project emerged, a development project for teaching, in blended learning (face-to-face and distance), to improve educational skills for students in the health professions. The project is an initiative of medical students from the School of Medical

REVISTA BRASILEIRA DE EDUCAÇÃO MÉDICA

2 44 (1) : e041; 2020 
and Health Sciences of the Pontifícia Universidade Católica de São Paulo (PUC-SP-FCMS), who had the supervision of two faculty members, familiarized with the active methodologies of health education and also with the collaboration of other experienced teachers from other higher education institutions (HEIs). The project is inspired by activities that involve students in the annual congresses and ongoing activities of the Association for Medical Education in Europe (AMEE) and in the activities of the FAIMER Júnior project that have been taking place in the congresses of the Brazilian Association of Medical Education (ABEM, Associação Brasileira de Educação Médica).

The first version of the FELLOWS Project took place throughout 2017 and was carried out with medical students from a single institution, the PUC/SP/FCMS, and was very successful. In 2018, it was extended to health students from other educational institutions and the project took on a new format, with two presential theme immersion blocks (Friday night, Saturday and Sunday) and a remote satellite session, on a virtual platform. The conception, form and content of this project proposal follow the National Curricular Guidelines of the Undergraduate Course in Medicine (DCNs, Diretrizes Curriculares Nacionais do Curso de Graduação em Medicina) and meet the demands of education in the health areas in Brazil ${ }^{1,2}$.

This report intends to disclose to the academic community of the health area HEIs our experience with the FELLOWS Project, in its versions of 2017 and 2018. The project objectives are: to promote, through a community of practice, the improvement in education of undergraduate students in the health area who are interested in a training and teaching career in their professional life; to promote, through active methodologies, education and training so that these students become familiarized with the strategies of education, leadership, management, interdisciplinary and team work and professional development, aiming at a future teaching career; to put knowledge into practice through the development of a teaching project (teamwork) for students in the health area, developed in different teachinglearning scenarios, preferably in the Unified Health System (SUS) locations.

\section{METHODOLOGY AND WORK ORGANIZATION IN THE FELLOWS PROJECT}

In 2017 the FELLOWS Project was developed by four medical students, two from the sixth year (UC and RMRC), one from the fifth year (JBM) and one from the fourth year (CAPB) of medical school. In 2018, a fourthyear student (ALCR) and a third-year student (SSP), who were tutors of the project in 2017, joined the coordinators. The project is supervised by two teachers from the medical course of FCMS at PUC-SP (MVP and FAA). It is an educational experience, which is organized in sessions, using active teaching-learning methodologies, particularly collaborative learning, which aims to establish a community of practice and were inspired by models that have already proved effective in consolidated education projects in the health area, such as FAIMER International and FAIMER Brasil, both aimed at teacher development for HEIs in the health area and the Projeto Preceptores, sponsored by the Brazilian Medical Education Association ${ }^{5,67}$.

\section{The FELLOWS Project 2017}

In 2017, the Fellows Project was carried out in its entirety on the premises of the medical school itself and took place from April to October, with discussion sessions and monthly meetings, which took place at night, or eventually on Saturdays, with the participation of guest professors, volunteers. Registration was open to medical students from the institution itself. Of the 35 enrolled students, 25 were selected. For this selection, the information obtained through a curriculum summary (Google Forms) was considered, where the students themselves explained their interest in participating, availability on the proposed dates, names, information related to graduation, languages (degree of proficiency) and their extracurricular activities. The information was supplemented during interviews that aimed to understand the student's motivation. The reason for limiting the selection to 25 students was the organizational capacity, based on the proposed model, structured from group formation, using active methodologies and seeking interaction. Among the 25 selected students, all were from PUC-SP/FCMS, 15 were women and 10 men. They were attending the $2^{\text {nd }}$ year $(n=3), 3^{\text {rd }}$ year $(\mathrm{n}=7), 4^{\text {th }}$ year $(\mathrm{n}=6), 5^{\text {th }}$ year $(\mathrm{n}=5)$ and $6^{\text {th }}$ year $(\mathrm{n}=4)$ of medical school. The mean age was 23 years old, ranging from 20 to 27 years old. Although it was not an exclusion criterion, everyone had a good knowledge of the English language, which facilitated their participation, since many texts and references provided were in the English language.

The activities of the FELLOWS Project in 2017 were very important for the training of the coordinating students themselves. We were able to count on the valuable collaboration of very experienced professors from PUC-SP/ FCMS, from the School of Medicine of Botucatu (UNESP) and from the School of Medical Sciences of UNICAMP, carrying out specific activities with the coordinating students' help. We also had the collaboration of two actors with degrees in performing arts and postgraduate degrees in education and involved in training activities for medical students at UNICAMP. The experience of working with these collaborators was essential for students to develop the skills necessary to conduct the FELLOWS Project in the following year and to create a teaching development center for students in health professions. The topics developed in 2017 were very similar to those that will be detailed for the FELLOWS Project 2018.

At the end of the project in 2017, the group of coordinators was strengthened and confident of having had a successful experience that would continue, and the participants already showed interest in continuing and being part of the working group. The project was presented at the Congresso Paulista de Educação Médica (UNICAMP, Campinas) in 2018 and aroused much interest from students and teachers. For this reason, we decided to extend it to students from other health education institutions.

The 2018 edition of the FELLOWS Project was prepared based on some considerations of the organizing group, such as: in 2017, the participation of students throughout the year conflicted with several commitments in the academic and social life of the participants, since it is common for the same student to be involved in many extracurricular activities; in 2018 there would be the participation of external students and, therefore, there was a need to concentrate the meetings and, finally, many students of the FELLOWS 2017 edition would like to participate in the immersion in 2018 .

\section{The FELLOWS Project 2018}

In 2018, the FELLOWS Project gained a new format and started to be structured into two blocks of thematic immersions in person and a remote satellite session on a virtual platform. The first immersion discussed essential skills in education and the second immersion specific skills in education. There was also a restructuring regarding coordination,

REVISTA BRASILEIRA DE EDUCAÇ̃̃o MÉDICA

3 44 (1) : e041; 2020 
with the inclusion of the two new coordinators, participants of FELLOWS 2017, and the creation of the tutor role, also students that participated in FELLOWS 2017. These new participants were selected from a registration notice, with the availability to participate in immersions, working with groups in distance activities and participating in training being fundamental criteria. As this is a student project, the intention was to include as many students as possible in the organization and carrying out of the project.

In FELLOWS 2018, the coordinators were the sessions' facilitators. All in-person educational activities were preferably carried out by, or had the participation of the coordinating students, even when there were invited guests. What we call coordinators (organizers) are students (some of which are now residents) who are interested and involved in medical education and who had training in this area of knowledge, acquired during their previous activities, effective participation (including organizational) in medical education congresses, in student activities and self-dedication. All activities developed in the FELLOWS Project are continuously and carefully studied, prepared, tested and simulated in advance by the coordinators and supervisors. During the activities, the participants are divided into small work groups (eight participating students and the guidance of a tutor throughout the sessions). As it will be shown below, the project seeks to address different aspects of education in the health professions, always using active methodologies, helping participants and organizers to get in touch with and live these experiences, so that all parties involved improve with the process.

In 2018, enrollment was open to students in the health area, including students from other institutions. The selection had the same characteristics of the 2017 project, plus the need to confirm availability for the immersion dates. Interviews with external candidates were carried out using the Skype ${ }^{\circledR}$ system. Although it was open to the participation of students in the health area, all individuals interested in the project were medical students and the final group of participants consisted of 13 students from the institution itself (PUC-SP/FCMS) and 11 students from other medical courses ( FAMERP; UFPR-Toledo; UFRJ; UNICAMP; UNIFESP; UFRBA; UP-PR and UVV-ES). Twelve were women and 12 men. They were attending the $2^{\text {nd }}$ year $(n=7), 3^{\text {rd }}$ year $(n=5), 4^{\text {th }}$ year $(n$ $=4), 5^{\text {th }}$ year $(\mathrm{n}=5)$ and $6^{\text {th }}$ year $(\mathrm{n}=3)$ of medical school. The mean age was 23 years old, ranging from 19 to 27 years old. Once again in 2018, everyone had a good knowledge of the English language. Students from other institutions who came to Sorocaba for the two immersion periods were welcomed and hosted by their colleagues in Sorocaba to minimize costs and provide greater integration.

\section{Ethical aspects}

Anticipating the need to make a formal evaluation of the project with the participants and its future publication also as a research project for the year 2018, the project was sent to the Research Ethics Committee of the FCMS of PUC-SP, where it was registered and approved under CAAE number 00995718.8.0000.5373.

\section{PROGRAM}

\section{First Immersion}

The in-person first immersion program in 2018 is shown in Table 1. Overall, the immersion sessions were carried out through discussion activities in 5 (five) small groups in the same environment (meeting

\begin{tabular}{|c|c|c|c|} 
Skills in Education - First Immersion Activities Program \\
Time & Topic & \multicolumn{1}{c}{ Objectives/Strategy } \\
\hline Friday & $\begin{array}{c}\text { Building the } \\
\text { Community of } \\
\text { Practice [Ref. 8,9] }\end{array}$ & $\begin{array}{l}\text { Introduce participants to the } \\
\text { concept of Community of Practice; } \\
\text { Encourage the creation of a } \\
\text { community of practice in the group. }\end{array}$ \\
\hline Saturday & &
\end{tabular}

\begin{tabular}{|c|c|c|}
\hline 08:00 - 11:00am & $\begin{array}{l}\text { Facilitation of } \\
\text { Learning: The } \\
\text { Different Roles of } \\
\text { the Teacher } \\
\text { [Ref. 10,11] }\end{array}$ & $\begin{array}{l}\text { Present characteristics expected for } \\
\text { the teacher; } \\
\text { Discuss the teacher's roles in } \\
\text { different scenarios; } \\
\text { Recognize the need and strategies } \\
\text { for teacher development; } \\
\text { Appreciate the importance of } \\
\text { teacher evaluation. }\end{array}$ \\
\hline 11:00 - 01:00pm & $\begin{array}{l}\text { Education Project } \\
\text { Clinical Learning } \\
\text { in Different } \\
\text { Scenarios } \\
\text { + Lunch on site }\end{array}$ & $\begin{array}{l}\text { What do we know? } \\
\text { Share practices, forms of teaching } \\
\text { and personal experiences on } \\
\text { different scenarios of learning in } \\
\text { practice. }\end{array}$ \\
\hline 01:00 - 05:00pm & $\begin{array}{l}\text { The Curriculum: } \\
\text { The Ladder of } \\
\text { Integration } \\
\text { [Ref. } 12,13,14]\end{array}$ & $\begin{array}{l}\text { Discuss curriculum organization } \\
\text { and integration tools; } \\
\text { Learn the stages of curricular } \\
\text { integration; } \\
\text { Learn the SPICES tool; } \\
\text { Stimulate the synthesis of ideas in } \\
\text { visual constructions. }\end{array}$ \\
\hline
\end{tabular}

Education Project

(Clinical Learning
05:00 - 06:00pm in Different
Scenarios)
+ Lunch on site

Sunday

08:00 - 11:00am

Student

Evaluation:

Methodology and

Application.

[Ref. 15,16,17]

Education Project

(Clinical Learning

11:00 - 02:00pm in Different

Scenarios)

+ Lunch on site

What is known and can be known?

Contextualize the problem

Present the types of evaluations;

Stimulate the association between

the types of evaluation and the skills

to be assessed;

Reflect on evaluations in practice.

What is our proposal?

Why are we proposing it?

Identify an effective teachinglearning methodology for a given scenario;

Justify the research work.
Formative

evaluation:

02:00 - 04:00pm

Feedback

[Ref. 18]

Education Project

(Clinical Learning

in Different

Scenarios)

04:00 - 05:00pm
Understand what feedback is;

Identify characteristics of effective or inappropriate feedback;

Associate feedback as a structuring activity of formative evaluation.

What do we know now?

Where do we want to go? Develop a map with what has already been researched;

Create the work schedule in group for the distance learning.
05:00 - 06:00pm

Closing 
room). In this format, a task is presented to groups with a pre-established time for discussion and preparation. Then, a group speaker presents the task results to the audience and this report is discussed by everyone with the mediation of the coordinators responsible for that task. At the end of the activity, the facilitators (coordinators) summarize what has been reported and discussed and present a short review with theoretical references, successful experiences or recommendations based on the best evidence in health education.

At the opening (Friday), there were presentations made by participants, tutors and coordinators and the immersion started with the "Building the Community of Practice" session, introduced to motivate the group towards collaborative work. The concept and principles of this learning strategy were practiced in the first session, as it is one of the FELLOWS Project's objectives. The social concept of community of practice was created by Etienne Wenger and Jean Lave as "groups of people who share a concern or passion for something they do and learn how to do it better as they interact regularly" ${ }^{8,9}$. Thus, these groups of people "when interacting, learn together and establish relationships, in addition to developing a sense of belonging and mutual commitment". The communities of practice are based on 3 fundamental characteristics: the common interest of the participants; the development of communication activities that allow sharing and learning from each other and having a practical application as a means and final objective.

The "Facilitation of Learning: The Different Roles of the Teacher" was included as an initial topic for the participants to broaden their perception and reflect on the usual activities of the medical professor.

The 2001 and 2014 DCNs indicate the need to train doctors to assume their roles in health care, management and health education, as health professionals prepared to meet the needs of their community and not just limited to the treatment of diseases ${ }^{1,2}$. The guidelines also reinforce the importance of the student-centered teaching, in order to guarantee the training of physicians with more autonomy and who are able to maintain a continuous process of learning and updating ${ }^{1,2}$. Thus, it is essential that the participant understands the changes in the future teacher's role in the teaching process, breaking with the idea of the simple transmission of knowledge in a specific area. The students must understand the different roles the teacher can assume in the teaching institution and understand that, to adequately carry them out, they will need specific skills and knowledge to perform well in their teaching task. Thus, it is important that future teachers be strengthened in their didactic-pedagogical training considering the most common areas of teaching in the health area, with special attention to the appropriate use of teaching-learning methodologies; evaluation techniques; care practice; the technical-scientific development; the management; the cooperative work; multidisciplinarity and interdisciplinarity, which will improve their teaching development and better curricular functioning ${ }^{10,11}$.

In the session "The Curriculum: Ladder of Integration", a challenging theme, the FELLOWS Project enabled its participants to experience the role of the teacher organizing the curriculum, allowing the discussion on the relationship between curriculum and pedagogical project; the curricular organization with an emphasis on disciplines or integration; integration tools and curricular integration stages and student participation in different models ${ }^{12-14}$. Also, to discuss the need to assess the adequacy of the chosen curricular model to the objectives to be achieved, its strengths and weaknesses based on the SPICES model ${ }^{14}$. The acronym SPICES represents six different aspects of the curriculum that can be represented as a spectrum or continuum between two extremes: Student-centered/ teacher-centered; Problem-based/information-gathering; Integrated/ discipline-based, Community-based/hospital-based, Elective/uniform and systematic/apprenticeship-based ${ }^{14}$.

Current student evaluation methods are focused on clinical skills (of communication - patient history and physical examination), skills to perform procedures and professionalism. The session "Student Assessment: Methodology and Application" intended to conceptualize and present the different types of evaluation (summative, formative and informative) and discuss the advantages and disadvantages of the main methods of student evaluation in written procedures (written test, multiple-choice tests, progress test, portfolio), of simulation (standardized clinical cases, performance of procedures, test stations) and in direct contact with the patient (clinical case, clinical mini-exam - Mini-CEx, observation of procedures $)^{15,16,17}$. It also discussed the correspondence between the competences to be evaluated and the most appropriate methods to address them, considering the reliability, standardization, reproducibility, technical feasibility (applicability in a given location), equivalence and cost (economic viability) of the different methods ${ }^{15,16}$. Practice-based methods were discussed with greater emphasis: clinical cases (long), Mini$\mathrm{CEx}$, direct observation of skills in procedures and peer review.

Feedback is a fundamental instrument of formative evaluation. It is the process in which the teacher and the student change in the tasks of teaching and learning. Feedback is the information given to the students to describe, analyze and qualitatively evaluate their performance in a given activity, comparing what would be expected for the circumstance in which the activity was carried out and for their degree of training. There are techniques for adequate feedback, which must be respected for it to be effective ${ }^{18}$. The future teacher needs to understand the complementarity of summative and formative evaluations and that the latter is an important pedagogical tool and one of the central components of the teachinglearning process ${ }^{17,18}$.

\section{INTERMEDIATE PERIOD - DISTANCE ACTIVITY}

Project in Education- Clinical Learning in Different Scenarios

Four groups of six students were created with their respective tutors and one tutor was left as a reserve. The groups were organized by the coordinators based on the participants' responses to the Team Roles Test questionnaire, which identifies the roles that each one of them best represent in a working group (https://www.123test.com/team-roles-test/). The groups were created according to the result indicated by the test, consisting of each student's preferred role aiming to create harmonious groups, facilitating teamwork. Each group was responsible for developing a teaching project on the topic of "clinical learning in its different settings". The recommendation made to the groups was that the activity aimed to develop the students' clinical skills and attitudes related to health care in different teaching-learning scenarios.

The teaching projects should necessarily address the following educational aspects in their construction: adequate teaching methodology; integration of health service-user-medical school; social accountability; evaluation and feedback of the teaching-learning process; practical feasibility of the teaching project. The four learning scenarios chosen

REVISTA BRASILEIRA DE EDUCAÇÃO MÉDICA

5 44 (1): e041; 2020 
were: hospital ward; outpatient clinic; basic health unit (with family health strategy) and home visit.

Throughout the immersions, the groups had periods when they worked together (see Table 1 and Table 2). In the first immersion, teamwork was used to share previous knowledge on the topic, contextualize the problem, point out a work proposal and justification. At the distance period, the groups should answer, through research, the questions, doubts and objectives raised in the in-person sessions and develop the work plan. The last details of the written project and the presentation took place in the second immersion.

\section{Second Immersion}

The second immersion was carried out four months after the first immersion and took place on Friday, from 18:00 to 20:30 (Table 2). After the welcome and familiarization with the coordinators and tutors, activities of communication skills were carried out with the coordination of two actors from the Ó Positivo Group at UNICAMP. The sessions on Saturday and Sunday took the form of discussion activities in small groups and in plenary, as already described for the first immersion. In addition to sessions aimed at developing more specific topics, there was a long session on Sunday where educational projects were presented and discussed in different scenarios, created in each group (at distance and in person) in the intermediate period of four months.

Among the specific topics was "The Guiding Values of Medical School". Considering that the mission of a medical school must go beyond the educational function of training doctors, as it also has the social mission of training sensitized professionals capable of caring for the population as a whole, with special attention to the health care model based on primary care, and considering the needs of underprivileged areas, the FELLOWS Project included in its activities a session with the objective of getting participants to reflect on the values and attitudes of social accountability in the medical school ${ }^{19}$. For that, he presented the concept of social accountability as an essential value in medical education. The ASPIRE Excellence - Social Accountability criteria and the areas of the Global Consensus on Social Accountability of Medical Schools were presented, generating discussion on the necessary attitudes for the medical school to incorporate social accountability as a guiding principle, considering its organization, function, teaching, research and care ${ }^{20,21}$.

Another topic of great interest, particularly for students from schools with a "traditional" curriculum structure was the "Problem Based Learning (PBL) and Mentoring". The PBL methodology was introduced to students and its advantages, disadvantages and progress were discussed ${ }^{22,23,24,25}$. Briefly, PBL was introduced in medical education at McMaster University (Canada) in the 1960s and later in Maastricht (Netherlands). Since then, many medical schools have adopted it and today it is widely used by new medical schools in Brazil. The method key point is the presentation of a real (or created) problem that causes the search for well-defined learning objectives, to be solved by a small group of students (8 to 10) in tutorial sessions (one teacher is the tutor) intermediated by periods of self-directed study. The tutorial sessions have a well-structured format and last from 2 to 3 hours. After reading the problem, students discuss and use prior knowledge to propose the solution strategy, establish the points that need to be clarified, the learning objectives and where to seek (study) the information. In the period between tutorial sessions, each student establishes their own type and time of study to meet their needs and, in the next tutorial session, re-discuss the problem by filling in the gaps with the new information, integrating and mutually complementing the acquired knowledge. After that, they developed together a conceptual map of the problem and at the end they perform their self-assessment and the evaluation of peers, tutor and problem.

\begin{tabular}{|c|c|c|}
\hline \multicolumn{3}{|c|}{$\begin{array}{ll} & \text { Table } 2\end{array}$} \\
\hline Time & Topic & Objectives \\
\hline \multicolumn{3}{|c|}{ Friday } \\
\hline 06:00 - 08:30pm & $\begin{array}{l}\text { Communication skills } \\
\text { Ó Positivo Group } \\
\text { (UNICAMP). }\end{array}$ & $\begin{array}{l}\text { Sensitize participants to } \\
\text { interpersonal communication skills. }\end{array}$ \\
\hline \multicolumn{3}{|c|}{ Saturday } \\
\hline 08:00 - 11:00am & $\begin{array}{l}\text { Guiding Values of the } \\
\text { Medical School. } \\
\text { [Ref. 19,20] }\end{array}$ & $\begin{array}{l}\text { Conceptualize social accountability } \\
\text { as an essential principle in medical } \\
\text { training; } \\
\text { Reflect on social accountability in } \\
\text { the medical school; } \\
\text { Present the ASPIRE Excellence - } \\
\text { Social Accountability criteria; } \\
\text { Present the Global Consensus on } \\
\text { Social Accountability of Medical } \\
\text { Schools. }\end{array}$ \\
\hline 11:00am - 01:00pm & $\begin{array}{l}\text { Education Project } \\
\text { Clinical Learning in } \\
\text { Different Scenarios } \\
\text { + Lunch on site }\end{array}$ & $\begin{array}{l}\text { What have we produced? } \\
\text { Finalize the final details of the } \\
\text { written project. }\end{array}$ \\
\hline \multirow{4}{*}{ 01:00 - 05:00pm } & \multirow{4}{*}{$\begin{array}{l}\text { Problem-Based } \\
\text { Learning (PBL) } \\
\quad \text { Mentoring } \\
\text { [Ref. } 22,23,24,25]\end{array}$} & $\begin{array}{l}\text { Learn the curriculum model based } \\
\text { on PBL; }\end{array}$ \\
\hline & & $\begin{array}{l}\text { Differentiate PBL } \quad \text { from } \\
\text { problematization; }\end{array}$ \\
\hline & & $\begin{array}{l}\text { Understand the problem } \\
\text { construction process (motivator); } \\
\text { Identify the members of a tutorial } \\
\text { session; }\end{array}$ \\
\hline & & $\begin{array}{l}\text { Learn the steps and the problem- } \\
\text { solving process in the tutorial } \\
\text { sessions. }\end{array}$ \\
\hline
\end{tabular}

\section{How to present?}

05:00-06:00pm Clinical Learning in Different Scenarios + coffee-break on site

Sunday Finalize the final details of the project presentation

\section{Here is our project:}

Present the project using active

Education Project

9:00am-01:00pm Clinical Learning in Different Scenarios methodology with broad participation and discussion of the other participating groups; Create space for exchange of experience between groups.

\section{1:00 - 02:00pm Lunch}

Discuss the weaknesses and potentials of the Fellows Project; Present the scenario constructed during the immersion.
02:00 - 05:00pm Feedback and closing 
At the FELLOWS project, each discussion group had the task of collectively creating a problem with their respective learning objectives to be developed in the period between immersions in a virtual learning environment, with the support of tutors and coordinators. Only two groups managed to complete this work, disclosing the expected difficulties of the teamwork carried out in the long term.

\section{REFLECTIONS ON THE FELLOWS PROJECT}

The FELLOWS Project is very significant for its creators and organizers, who recognize the possible contributions to education in the health professions and, due to its specificity, to medical education. In addition to the obvious personal benefits for the organizers and participants, since preparing teaching activities is the best way to learn, one should also consider the benefits for educational institutions, which will have more prepared, engaged and critical students in the conception and development of curricular activities, in the most effective participation in academic life, assuming their social accountability and recognizing those inherent to Education Institutions. Although the number is small, this group of students was awakened to this professional activity, teaching, of which training opportunities are scarcely available. Currently, we have few stricto sensu postgraduate programs in the health area that are specifically aimed at teacher education. Most of the postgraduate programs recognized and recommended by the Coordination for the Improvement of Higher Education Personnel (CAPES, Coordenação de Aperfeiçoamento de Pessoal de Nivel Superior) have as their main objective the training of researchers and not of teachers for higher education. During graduation, the aspect of teacher training is not included in the curricula of courses in the health area and, in most cases, it is restricted to monitoring. Thus, HEIs gain a group of students interested in teaching as a possible area of professional activity in the future and, at the same time, will have among their students people interested in evaluating, analyzing and being critical in relation to the development of the curriculum and the course pedagogical activities, which can be very useful for the institution.

\section{Benefits for participating students}

In addition to the already mentioned benefits, many studies have indicated that the participation of students and residents in the regular curricular activities of the health area courses, particularly Medicine, improve the capacity for learning, guidance, leadership, management; they favor interpersonal relationships and the acquisition of communication skills, student engagement and student social accountability ${ }^{3,4}$.

\section{Benefits for coordinators and supervisors}

Conceiving, organizing, preparing to perform, experience and analyze what has been done are among the greatest benefits that the coordinators (organizers) of the FELLOWS Project could achieve. According to Paulo Freire, "under conditions of true learning, students become real subjects of the construction and reconstruction of the taught knowledge, alongside the educator, who is also the subject of the process" ${ }^{26}$. Therefore, the teaching activity committed and willing to receive and understand the student as an equal, with their previous knowledge and cultural experiences, is the greatest learning experience that the teacher can have. Teacher and student learn together and assist each other during that learning process. Thus, developing the FELLOWS Project was and will continue to be a great learning experience for organizers and supervisors. Being able to count on collaborators from other HEIs in the health area at the beginning of the process was essential to create this teaching development core consisting of medical students and aimed at students of the health professions.

What can be improved and future steps

Discussions informally held between the coordinators and those held regularly after the (formal) activities identified the formal evaluation of the project as the greatest future need. It is necessary to document the opinions and suggestions of the participants, the coordinators and, if possible, teachers of the institutions that house the participants of the FELLOWS Project, seeking to evaluate whether (and how) the student's participation in the project influenced their academic life.

The project will continue in 2019 with the renewal of part of the coordinators, following the same model of 2018, with two immersion meetings and an educational project carried out in a group at distance.

\section{ACKNOWLEDGMENTS}

We would like to thank everyone who has somehow contributed to the success of this experience, particularly the coordinators (organizers), tutors, participants (students and residents) and especially, the internal collaborators (Prof. Dra. Maria Helena Senger) and invited guests (Prof. Dra. Eliana Amaral - UNICAMP, Prof. Dra. Jacqueline Costa Teixeira Caramori - UNESP - Botucatu, Adilson Doniseti Ledubino and Letícia Rodrigues Frutuoso from the Ó Positivo Group - UNICAMP). We would also like to thank the support of the Coordination of the Medical Course and the Direction of the Medical School and Health Sciences of PUC-SP, the Board of Directors and many colleagues from Regional São Paulo of ABEM and the National Board of Directors of ABEM, particularly Prof. Lucia Christina Ioshida and Prof. Sigisfredo Luiz Brenelli, who always showed interest, encouraged and publicized the initiative among their peers, students and residents.

The report of this experience was presented at the $55^{\text {th }}$ Brazilian Congress of Medical Education in November 2018 as a summary and commented poster.

\section{REFERENCES}

1. Brasil. Ministério da Educação. Conselho Nacional de Educação. Resolução CNE/CES no 4, de 7 de novembro de 2001. Institui Diretrizes Curriculares Nacionais do Curso de Graduação em Medicina. Brasília; 2001.

2. Brasil. Ministério da Educação. Conselho Nacional de Educação. Resolução CNE/CES no 3, de 20 de junho de 2014. Institui Diretrizes Curriculares Nacionais do Curso de Graduação em Medicina. Brasília; 2014.

3. Steinert Y. Developing medical educators: a journey, not a destination. In: Swanwick T., editor. Understanding medical education: evidence, theory and practice. 2. Ed. Oxford: Wiley-Blackwell, Oxford; 2014. p. 455-72.

4. Dandavino M, Snell L, Wiseman J. Why medical students should learn how to teach. Med. teach. 2007; 29:558-65.

5. The Foundation for Advancement of International Medical Education and Research. Available from: https://www.faimer.org/.

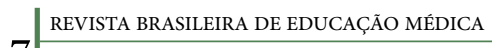

7 44 (1) : e041; 2020 
6. Brasil-FRI. Instituto Regional FAIMER Brasil. Available from: https://brasil.faimerfri.org/.

7. Associação Brasileira de Educação Médica. O preceptor por ele mesmo. Cadernos da ABEM 2013;9:5-106. Disponível: https:// website.abem-educmed.org.br/wp-content/uploads/2019/09/ CadernosABEM_Vol09.pdf.

8. Wenger-Trayner E, Wenger-Trayner B. Introduction to communities of practice: a brief overview of the concept and its uses. 2015. Available from: https://wenger-trayner.com/wp-content/uploads/2015/04/07Brief-introduction-to-communities-of-practice.pdf.

9. Ranmuthugala G, Plumb J, Cunningham FC, Georgiou A, Westbrook JI, Braithwaite J. How and why are communities of practice established in the healthcare sector? A systematic review of the literature. BMC health serv. res. 2011;14(11):273.

10. Harden RM, Crosby JR. The good teacher is more than a lecturer: the twelve roles of the teacher: AMEE Guide $n^{\circ} 20$. Med. teach. 2000;22(4):334-47.

11. Machado MMBC, Sampaio CA, Macedo SM, Figueiredo MFS, Rodrigues Neto JF, Lopes IG, et al. Reflexões e significados sobre competências docentes no ensino médico. Avaliação (Campinas) 2017;22(1):85-104.

12. Harden R. The integration ladder: a tool for curriculum planning and evaluation. Med. educ. 2000;34(7):551-7.

13. Hammick M, Freeth D, Koppel I, Reeves S, Barr H. A best evidence systematic review of interprofessional education: BEME Guide $\mathrm{n}^{\circ} 9$. Med. teach. 2007;29(8):735-51.

14. Harden RM, Sowden S, Dunn WR. Educational strategies in curriculum development: the SPICES model. Med. educ. 1984;18(4):284-97.

15. Shumway JM, Harden RM. The assessment of learning outcomes for the competent and reflective physician: AMEE Guide $n^{\circ} 25$. Med. teach. 2003;25(6):569-84.

16. Norcini JJ, McKinley DW. Assessment methods in medical education. Teach Teacher Educ 2007;23:239-50.

17. Troncon LEA. Estruturação de sistemas para avaliação programática do estudante de Medicina. Rev. bras. educ. méd. 2016;40(1):30-42.

18. Borges M, Miranda C, Santana R, Bollela V. Avaliação formativa e feedback como ferramenta de aprendizado na formação de profissionais da saúde. Medicina (Ribeirão Preto). 2014;47(3):324-31.

19. Ellaway RH, Malhi R, Bajaj S, Walker I, Myhre D. A critical scoping review of the connections between social mission and medical school admissions: BEME Guide no 47. Med. teach. 2018;40(3):219-26.
20. Harden RM, Roberts TE. ASPIRE: international recognition of excellence in medical education. Lancet 2015;385(9964):230.

21. Consenso Global de Responsabilidade Social das Escolas Médicas. Available from: http://healthsocialaccountability.sites.olt.ubc.ca/ files/2012/02/GCSA-Global-Consensus-document_portuguese.pdf.

22. Santos SR. O aprendizado baseado em problemas (Problem-based learning - PBL). Rev. bras. educ. méd. 1994; 18(3):121-4.

23. Azer SA, Peterson R, Guerrero AP, Edgren G. Twelve tips for constructing problem-based learning cases. Med. teach. 2012;34(5):361-7.

24. Maia JA. Metodologias problematizadoras em currículos de graduação médica. Rev. bras. educ. méd. 2014;38(4):566-74.

25. Bate E, Hommes J, Duvivier R, Taylor DC. Problem-based learning (PBL): getting the most out of your students - their roles and responsibilities: AMEE Guide ] 84. Med. teach. 2014;36(1):1-12.

26. Freire P. Pedagogia da autonomia: saberes necessários à prática educativa. 43. ed. São Paulo: Paz e Terra; 2011.

\section{AUTHORS' CONTRIBUTIONS}

This project was proposed by the first author (UC) to his undergraduate colleagues, when they were students, based in his personal experiences in the area of medical education. The project took shape and can be developed with the support and guidance of two professors from the medical course (MVP and FAA). It is a collective construction and all authors participated equally in all stages of the project. We count on the help and enthusiasm of all participating students. This "experience report" was written by FAA with the contribution, in all stages, of all coordinating participants.

\section{CONFLICTS OF INTEREST}

The authors declare no conflict of interest at all.

\section{ADDRESS FOR CORRESPONDENCE}

Fernando Antonio de Almeida. Rua Joubert Wey 290, Jardim Vergueiro, Sorocaba, SP, Brasil.

CEP: $18030-070$.

E-mail: faalmeida@pucsp.br or almeidafa@globo.com 